P32 上る 実験的日本脑炎の研究

$$
\text { 第三編 }
$$

腹腟内病毒接種マウス臟器（脳，肝）に於ける核酸代謝の

核酸鏻比放射能偟よる研究

岡山大学医学部平木内科敬室（主任：平木 知数授)

松久光雄

[昭和 32 年 10 月 2 日受稿]

第一章 緒 言

第二章 実験材料並飞実験方法

第一節 実験材料

第二節 実験方法

\section{第一童 楮言}

近時原子物理学の進步々共飞人工放射性同 位元素が生物学或は医学の領域に応用せられ るよろになつて華々しい成果を挙げているが， 最近江於ける放射性同位元素の応用範囲は更 にウイルスにも及んで，ウイルスに関する研 究は飛躍的な進步をみせつつある.

即ち 1942 年 Stanley 27) がタバコモザイク ウイルスの研究炲めて放射性同位元素を用 いて以来，Graham ${ }^{19}$ ) の放射性橉（以下 P $^{32}$ と略す）によるインフルエンザウイルスの核 酸代樈の研究，更飞 Putman 23)，Cohen ${ }^{14)}$ 等 の $\mathrm{P}^{32}$ 火上る大腸菌ウイルスの研究等幾多の 業靕が続出している。

本邦飞於ても1952年堀田等10) テング熟感染マウス䐵器の燐代暗を研究し， 感染極期飞核酸を中心とした物質飞激しい変 動が括てることを明かにしているが，日本脳 炎罪患マウス媵器飞放射性同位元菜とい5新 しい手段を用いて研究し，ウイルス感染と伴 万宿主細胞の動きを観祭したのは教室の長 田4) 及び内田2)である。

即ち長田は $\mathrm{P}^{32}$ を tracer として用い脳炎
次

第三章 実験成績

第四章 総括並飞考按

第五章 結 諭

文献

ウイルス脳内接種マウスの脳及び肝に於ける 核酸代謝を追求し，続いて内田 ${ }^{2)}$ \&肺，脾， 堅飞於ける核酸代謝を同橉 Schneider 法26) 飞 .より研究し， $\mathrm{P}^{32}$ 活性度の測定飞より何れる

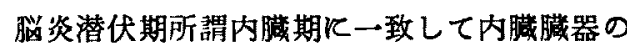
核酸関連した物質飞激しい変動の括こるこ とを明かとした。

先飞私も腹腔内ウイルス接種マウス脳及び 肝の核酸代謝を Schmidt-Thannhauser 法 ${ }^{25)}$ により研究し，肝では既飞潜伏期飞於て R.N.A（リボ核酸）及び D. N.A（デゾオキ ンリホ核酸）各分劃の $\mathrm{P}^{32}$ 活性度は共飞增大 の傾(们を示し，長田4) の脳内接種法とほほ同

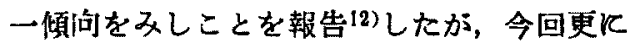

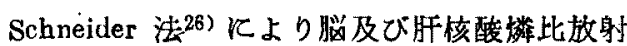
能を求め再吟味せんと意企した。

大力諸算の御批判を乞う次籍である。

\section{第二章 実験材料並に実酸方法}

第一節 実験材料

（1）日本脳炎病毒

(2) $\mathrm{P}^{32}$

（3） 実䮖動物

以上のすへてては第一編及び第二編と使用せ 
しすのと同一なるすのを用いた。

\section{第二節 実験方法}

教室保存の岡山52 B 株の脳内接㮔とより两 患発症し攧死期にあるマウス脳を $\mathrm{pH} 7.4$ の フイヨンで 10 \%乳戍を作り遠心沈没（毎分 3000 回転 10 分間) し，その上清を $0.3 \mathrm{cc}$ 夗 多数のマウス腹腔内に接種した。

な括予筩実験として脳炎ウイルス $0.3 \mathrm{cc}$ 腹 腔内接種マウスは発症を括こすに 6 日間を要 することを確めている.

その後時間的経過を追いウイルス接種後約 48 時間，及び 120 時間の 2 回，即ち潜伏期及 び発症期に $\mathrm{P}^{32} 10 \mu \mathrm{c}$ 宛を腹腔内に注射した。 その後両期ともに 6 時間及び 24 時間を経て， それぞれ無選択的に 4〜5匹宛のマウスを取 り出し頸動脈を切断して故血死せしめ, 䑏器 （兴及び肝）を取り出して次に述へる処置を 施した。

な招対照としては，硉康マウス脳乳刘を趾 康マウス腹䶼内に同様に接偅し，同じく48時 間及び 120 時間の後 $\mathrm{P}^{32} 10 \mu \mathrm{c}$ 宛腹腔内飞注 射し，それぞれ 6 時間及び24時間を経て殺し 以後同様の操作を行つた。

各滕器を取り出すに当つては生理的食塭水 で充分洗深し，滤紙上で充分水分を拭きとり 出来るだけ血液成分を除去するようと努めた。 而して採取せる脳及び肝の $1 \mathrm{~g}$ を正確に秤量 し Schneider 法 ${ }^{26)}$ 飞従い(1)酸可溶性燐分劃 （燐酸，モノヌクレオチド，糖類その他低分 于燐酸エステ儿等を含せ) (2) 榤脂質分劃 (3) 核酸分劃 (4) 橉蛋白分劃化分加ちた．即ち (1) 酸可溶性燐分劃：各媵器の一定量の20％市モ シネート $1.0 \mathrm{cc}$ 《 $10 \%$ 水冷卜リクロール酛 酸（TCA） $2.5 \mathrm{cc}$ を加光速か飞速心分離する。

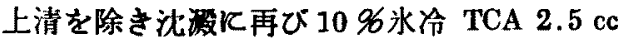
を加え䜿濁液となし速か汇薏心分離する，沈 泚は次の橉脂質分割に利用する。この上清は 先の上清と合併して酸可溶性橉分劃として除 去する。

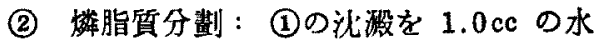

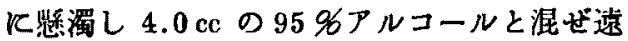
心分離する. 视没を $5.0 \mathrm{cc}$ のアルコールK悪
濁し再び遠心分離して (1)で用いられた TCA を出来るだけ除去する．次に沈澱をアルコー ル－エーテル混液（3：1）5.0 cck瑟濁し温 浴中て 3 分間沸騰せしめる。冷後遠心分離し 得られた沈㴊を同様操作して計 3 回抽出する。 3 回分のアルコール・エーテル抽出液を合併 し燐脂質分劃として除去する。

(3) 核酸分劃：(2)の沈澱を $1.2 \mathrm{cc}$ の冷水 飞㲘濁し $10 \%$ 水冾 TCA $1.3 \mathrm{cc}$ を混じ遠心分 離する，次に沈错を 5 \% TCA $5.0 \mathrm{cc}$ 中再 び㷂濁し $90^{\circ} \mathrm{C}$ の湯浴中で15分間加熱後冷却

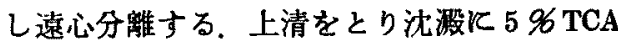
$2.5 \mathrm{cc}$ を加えよく混ぜてから遠心分離する。 これらの抽出液を合併して核酸分割とし保存 して括く.

(4) 燐蛋白分劃：(3)の沈澌を2 96 苛性ソー タ飞溶解せしめて得られるが，奏験に必要な き故(3の沈激をそのまま除去する。

次飞保存し括きし核酸分劃の $\mathrm{P}^{32}$ 放射能活 性度 (Counts/Min/1.0 g) 及び䑏器核酸能量 (P31 $\mathrm{mg} \%$ ) を測定し䐵器核酸橉比放射能 ( $\mathrm{P}^{32}$ $\mathrm{Cpm} / \mathrm{P}^{31} \mathrm{mg}$ ), 即与膈器核酸橉一定量当りの 放射性核酸燐量を求めた。 $\mathrm{P}^{32}$ 放射能活性度 （P活性度と略す）の測定は，第二編に述 ベし如くキエルダールフラスコに入れ硫酸硝 酸で湿式灰化の上，燐を撛酸マグネンウムア ンモンとして视涮し，その放射能を GeigerMüller管により測定した，又臟器核酸燐量の 測定は第一編に述へし如く，(3の上清の一定 量をとり湿式灰化後 Fiske-Subbarow 法18) V より生成した青色をベックマン分光光度計に て比色し，手め作製した検量曲線に基いて燐 量を求めた。

\section{第三章 実 跙 成 䋨}

1）潜伏期飞於ける脳核酸橉比放射能を第 1 表に，その平均值を第 1 図に示した。

即ち潜伏期初期 ( $\mathrm{P}^{32}$ 注射後 6 洔間) 及び 後期 ( $\mathrm{P}^{32}$ 注射後24時間) の比放射能（Specific Activity＝以下 SA と略す）を比較検討し てみるに，ウイルス接種群の SA は共にその 刘照群に比し增大を示し，又両者の間では後 
第 1 表 脳核酸燐比放射能 $\left(\mathrm{P}^{32} \mathrm{Cpm} \times 100 / \mathrm{P}^{31} \mathrm{mg}\right)<$ 潜伏期 $>$

\begin{tabular}{|c|c|c|c|c|c|c|c|c|c|c|c|c|}
\hline \multirow{3}{*}{ 試 } & \multicolumn{6}{|c|}{$P^{32}$ 注射後 6 時間 } & \multicolumn{6}{|c|}{ P32 注射後 24 時間 } \\
\hline & \multicolumn{3}{|c|}{ クイルス接種群 } & \multicolumn{2}{|l|}{ 対 } & \multirow{2}{*}{$\frac{\text { 群 }}{\text { SA }}$} & \multicolumn{3}{|c|}{ ウイルス接種群 } & \multirow[b]{2}{*}{$\mathrm{Cpm}$} & 照 & \multirow{2}{*}{$\frac{\text { 群 }}{\text { SA }}$} \\
\hline & Cpm & $\begin{array}{l}\mathrm{mg} \\
(\mathscr{6})\end{array}$ & $\mathbf{S A}$ & Cpm & $\begin{array}{c}\mathrm{mg} \\
(\%)\end{array}$ & & $\mathrm{Cpm}$ & $(\%)$ & SA & & $(96)$ & \\
\hline I & 21 & 106 & 19.8 & 18 & 98 & 18.3 & 25 & 100 & 25.0 & 22 & 125 & 17.6 \\
\hline II & 23 & 109 & 21.1 & 23 & 110 & 20.9 & 24 & 99 & 24.2 & 25 & 130 & 19.2 \\
\hline III & 28 & 110 & 25.4 & 21 & 109 & 19.2 & 27 & 97 & 27.8 & 19 & 111 & 17.1 \\
\hline IV & 28 & 101 & 27.7 & 23 & 115 & 20.0 & 28 & 104 & 26.9 & 26 & 118 & 22.0 \\
\hline 平均 & & & 23.5 & & & 19.6 & & & 25.9 & & & 18.9 \\
\hline
\end{tabular}

第 1 図脳核酸橉比放射能平均值

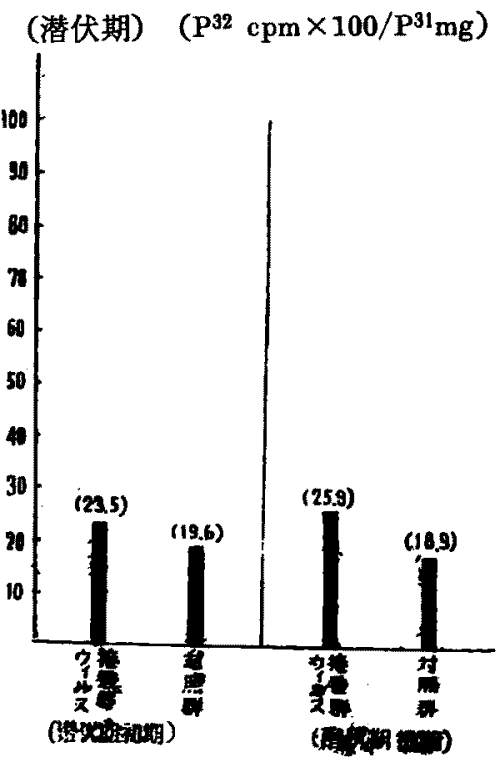

第 2 四脳核酸燐比放射能平均值

（発症期）（ $\mathrm{P}^{32} \mathrm{cpm} \times 100 / \mathrm{P}^{31} \mathrm{mg}$ ）

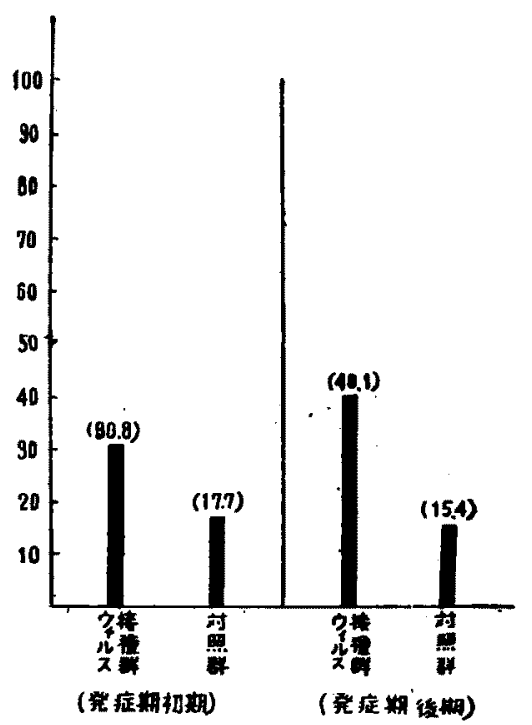

第 2 表 脳核酸燐比放射能 $\left(\mathrm{P}^{32} \mathrm{Cpm} \times 100 / \mathrm{P}^{31} \mathrm{mg}\right)<$ 発症期>

\begin{tabular}{|c|c|c|c|c|c|c|c|c|c|c|c|c|}
\hline \multirow{3}{*}{ 武 } & \multicolumn{6}{|c|}{$\mathrm{P}^{32}$ 注射 後 6 時間 } & \multicolumn{6}{|c|}{ P92 注 射後 24 時 間 } \\
\hline & \multicolumn{3}{|c|}{ ウイルス接種群 } & \multicolumn{2}{|l|}{ 対 } & \multirow{2}{*}{$\frac{\text { 群 }}{\text { SA }}$} & \multicolumn{3}{|c|}{ ウイルス接種群 } & \multicolumn{2}{|c|}{ 对 照 } & \multirow{2}{*}{$\begin{array}{c}\text { 群 } \\
\mathbf{S A}\end{array}$} \\
\hline & Cpm & $\begin{array}{l}\mathrm{mg} \\
(\%)\end{array}$ & $\mathbf{S A}$ & $\mathrm{Cpm}$ & $\begin{array}{l}\mathbf{m g} \\
(\mathscr{6})\end{array}$ & & $\mathrm{Cpm}$ & $\stackrel{\mathrm{mg}}{(\not 6)}$ & SA & Cpm & $\begin{array}{l}\mathrm{mg} \\
(96)\end{array}$ & \\
\hline I & 40 & 131 & 30.5 & 26 & 128 & 20.3 & 58 & 151 & 38.5 & 16 & 129 & 12.4 \\
\hline II & 41 & 135 & 30.3 & 19 & 124 & 15.3 & 64 & 155 & 41.2 & 20 & 128 & 15.6 \\
\hline III & 47 & 138 & 34.0 & 22 & 131 & 16.8 & 70 & 160 & 43.7 & 21 & 135 & 15.6 \\
\hline IV & 38 & 133 & 28.5 & 25 & 135 & 18.5 & 62 & 167 & 37.0 & 24 & 134 & 17.9 \\
\hline 平均 & & & 30.8 & & & 17.7 & & & 40.1 & & & 15.4 \\
\hline
\end{tabular}

期の SA により増大の傾向がみられた.

2）発症期浪於ける脳核酸撛比放射能を第

2 表に，その平均值を第 2 図に示した。
即ちウイルス接俥群のSA は発症期初期よ り後期にかけてその対照群に比し益々有意の 差を認め, 脳核酸橉比放射能は潜伏期初期よ 
り潮次增大し発症期に入り急激に増大するの が認められた，又発症期初期，後期，共飞核 酸橉量の増加飞伴いてウイルス接種群の SA の増大を認めた。

3）潜伏期に於ける肝核酸燐比放射能を第
3 表に，その平均值を第 3 困に示した。

即ちウイルス接種群の SA 初期, 後期, 共にその対照群に比し明かに増大を示し，特 飞初期に於ては顕著な增大をみるのが注目さ れる.

第 3 表 肝核酸橉比放射能 $\left(\mathrm{P}^{32} \mathrm{Cpm} \times 100 / \mathrm{P}^{31} \mathrm{mg}\right)<$ 潜伏期>

\begin{tabular}{|c|c|c|c|c|c|c|c|c|c|c|c|c|c|}
\hline \multirow{3}{*}{ 試 } & \multirow{3}{*}{ 料 } & \multicolumn{6}{|c|}{ P32 注射後 6 時間 } & \multicolumn{6}{|c|}{ P32 注 射 後 24 時間 } \\
\hline & & \multicolumn{3}{|c|}{ ウイルス接種群 } & \multirow{2}{*}{$\frac{\text { 対 }}{\mathrm{Cpm}}$} & 照 & \multirow{2}{*}{$\frac{\text { 群 }}{\text { SA }}$} & \multicolumn{3}{|c|}{ ウイルス接種群 } & \multicolumn{2}{|l|}{ 対 } & \multirow{2}{*}{$\frac{\text { 群 }}{\text { SA }}$} \\
\hline & & Cpm & (q) & SA & & $(\mathrm{mg})$ & & Cpm & $\stackrel{\mathrm{mg}}{(96)}$ & $\mathbf{S A}$ & Cpm & $\stackrel{\mathrm{mg}}{(\%)}$ & \\
\hline \multicolumn{2}{|c|}{$\mathrm{I}$} & 77 & 91 & 84.5 & 71 & 109 & 65.0 & 85 & 132 & 64.5 & 62 & 138 & 44.9 \\
\hline \multicolumn{2}{|c|}{ II } & 68 & 101 & 67.3 & 70 & 103 & 68.0 & 70 & 138 & 50.7 & 69 & 149 & 46.4 \\
\hline \multicolumn{2}{|c|}{ III } & 70 & 89 & 78.6 & 59 & 115 & 51.5 & 86 & 144 & 59.7 & 70 & 150 & 46.6 \\
\hline \multicolumn{2}{|c|}{ IV } & 78 & 96 & 81.0 & 62 & 112 & 55.3 & 83 & 139 & 59.7 & 68 & 135 & 50.3 \\
\hline & & & & 77.9 & & & 60.0 & & & 58.7 & & & 47.1 \\
\hline
\end{tabular}

第 3 図肝核酸橉比放射能平均值

（潜伏期）（ $\mathrm{P}^{32} \mathrm{cpm} \times 100 / \mathrm{P}^{31} \mathrm{mg} ）$

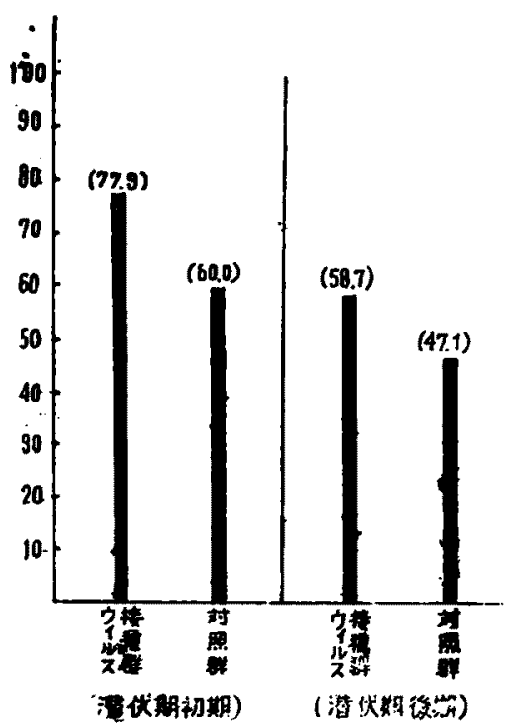

第 4 図肝核酸橉比放射能平均值 （発症期）（ $\left.\mathrm{P}^{31} \mathrm{cpm} \times 100 / \mathrm{P}^{31} \mathrm{mg}\right)$

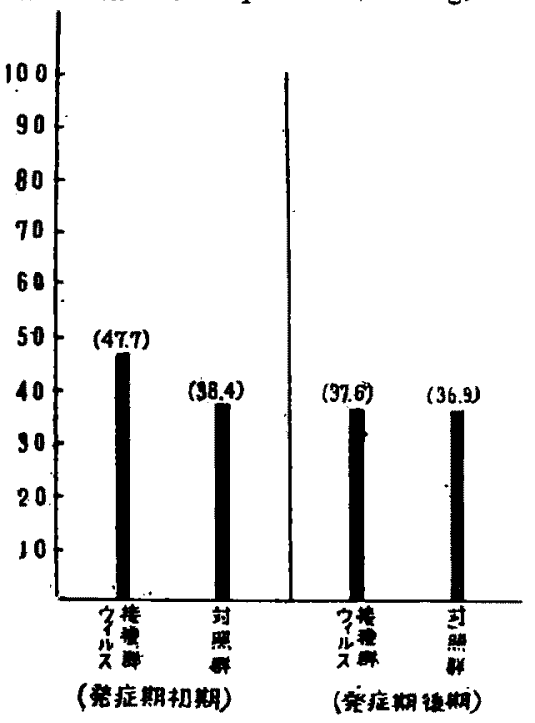

第 4 表 肝核酸燐比故射能 $\left(\mathrm{P}^{32} \mathrm{Cpm} \times 100 / \mathrm{P}^{31} \mathrm{mg}\right)<$ 発症期>

\begin{tabular}{|c|c|c|c|c|c|c|c|c|c|c|c|c|c|}
\hline \multirow{3}{*}{ 試 } & \multirow{3}{*}{ 料 } & \multicolumn{6}{|c|}{ P32 注 射後 6 峙間 } & \multicolumn{6}{|c|}{ P32 注射後 24 時 間 } \\
\hline & & \multicolumn{3}{|c|}{ ウイルス接種群 } & \multicolumn{2}{|c|}{ 対 } & \multirow{2}{*}{$\frac{\text { 群 }}{\mathrm{SA}}$} & \multicolumn{3}{|c|}{ ウイルス接種群 } & \multicolumn{2}{|c|}{ 対 照 } & \multirow{2}{*}{$\frac{\text { 群 }}{\mathrm{SA}}$} \\
\hline & & Cpm & $\stackrel{\mathbf{m g}}{(\mathscr{6})}$ & SA & Cpm & $\begin{array}{c}\mathrm{mg} \\
(\mathscr{6})\end{array}$ & & Cpm & $(\%)$ & SA & Cpm & $\begin{array}{c}\mathrm{mg} \\
\left(\phi^{\circ}\right)\end{array}$ & \\
\hline & & 69 & 147 & 47.0 & 52 & 145 & 35.9 & 59 & 176 & 33.5 & 54 & 138 & 39.2 \\
\hline & & 72 & 135 & 53.3 & 59 & 142 & 38.9 & 68 & 183 & 37.2 & 47 & 138 & 34.0 \\
\hline & & 68 & 140 & 48.5 & 58 & 160 & 36.3 & 67 & 170 & 39.4 & 57 & 145 & 39.3 \\
\hline & & 63 & 149 & 42.2 & 63 & 148 & 42.6 & 64 & 169 & 40.2 & 50 & 142 & 35.2 \\
\hline & 均 & & & 47.7 & & & 38.4 & & & 37.6 & & & 36.9 \\
\hline
\end{tabular}


又潜伏期に於ける脳核酸燐比放射能飞較へ 初期, 後期, 共飞極めて有意の高值を示して いる.

4）発症期に於ける肝核酸橉比放射能を第 4 表に, その平均値を第 4 図に示した.

即ちウイルス接俥群の SA は初期, 後期, 共にその対照群に比しては增大を示せど，急 激に减少の傾向を示している。

又発症期後期飞核酸燐量の增大が認められ たが，脳の場合と異りSA は逆に減少を示し ているのが注目される。

\section{第四草 枱括並に考按}

以上総括するに脳に於けるウイルス接橧群 のSA は，その対照群飞比し潜伏期初期より 発症期後期にかけ濑次相加的飞增大の傾向が みられ，特飞発症期に入り急激な增大がみら れる。肝飞於ては潜伏期特にとの初期飞は非 常徏顕著な增大を示すが，発症期に入ると急 激なる滅少の傾向がみられる。

又脳に於ては発症期に於けるウイルス接种 群の核酸僯量の増加に併行してその SA の増 大を認めるる，肝に於ては発症後期に於ける 核酸燐量の増加にも拘わらず，その SA は逆 そ減少しているのが注目される。

さて脳に於ける無機燐と有機橉酸エステル との間に急速な燐の交替が行われるととは， Lindberg 及び Ernster ${ }^{22)}$, Sacks 及び Gulb. reth 等24)の報告により明かであり，更飞燐脂

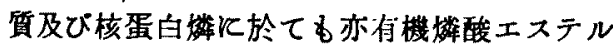
程速かでないが絶えず燐の交替が行われてい ることは Chaikoff(13) 等, Dawson ${ }^{(6)}$; 中无等 により証明せられている。

Chaikoff ${ }^{(3)}$ 等は橉脂質の橉酸基は斯機橉酸 より附加せられるものでなく，恐らく有機燐 酸エステル特倍エネルギー橉酸エステルよ り附加せられるるのであろうといつている。

脳組織に接桶せられた無機撛は速かに有機 燐酸エステル類に合成せられ2224)，更にこの 両者は短時間内（約30分）飞平衡状態に達し， 無機燐の比放射能と有機橉酸エステルの比放 射能とはほほ等しくなることが証明されてい
る.

從つて一定時間後に於ては有機燐酸エステ ルの比放射能を現わす值として，両者を含む 酸可溶性燐の比放射能を充当して子不合理て はないとされている22)。

核酸磷の橉交替率飞於ては叙上の如き立証 に接しないが，Dawson ${ }^{17)}$ 等は燐脂質の場合 と同样の考方方からその燐交替率を算出して 扮り，中沢7をこれを採用することが不合理 でないと考え奏駼を行つている.

然かし Tuttle ${ }^{28)}$ 等は動物例之ばマウスに $\mathrm{P}^{32}$ 粼酸程が入れは，先ず血墏燐酸塩となり 組織に達して細胞内に渗逶し次いで核酸の構 成成分になると云い, Hevesy ${ }^{20)}$ 及び Chiewitz ${ }^{20)}$ とよると投与された $\mathrm{P}^{32}$ は細胞間液の 噒と交換が行われ，次いで核酸の諸成分にな ると述へ，甲論，乙駁，明確な意見の一致を みていない，

そもそる $\mathrm{P}^{32}$ により核酸代謝を検討する際， その交替の度を表わす方法は諸家により色々 である。即ち脿器の一定湿量中の放射性核酸 燐量を以てする方法，搭器核酸燐一定量当り の放射性核酸矮量即ち比放射能を以てする法, 更には核酸燐比放射能の無機燐比放射能に対 する百分詈，即ち相対比放射能飞よる法の三 法がある、最初の方法は核酸燐代辣の動的な 面を示さず，後二者については何れが適当で あるか決論がないが，この両者は平行して增 減して相反することはない様であり，私は叙 上の如き理由より比放射能を採つた.

今日, 日本脳炎悩脳の病変の追求を主眼と した従来の観点とは異つて，専ら全身感染と い弓見地から追求されている.

この端緒となつたのは楮方, 高术 ${ }^{3)}$ の報告 で，本泟は中枢神释のみならず各内歲に一定 の病変のみられることから企身感染症であり，

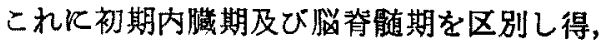
更飞初期病㱟血症の存在が非態学的飞認めら れることを明がしている。

諏訪5) は本症の内㼄の動きを形態学的にみ ると，ての企身感染の表現である葴器の変化 （主として肝と脾）は極めて速かに極期に達 
しかつ速かに消退するすのと考え，その極期 は形態学的にみて結局 $2 \sim 3$ 病日位にあり, 4 病日以降恃比較的速加消退寸ると述へて いる.

かかる緒方3) の所謂内葴期に於ける臓器の 変化を始めて人工放射性同位元素を用いて追 求し，もつて脳炎の全身感染症としての特性 を核酸代謝の面より明かにしたのは，教室長 田はである。

即ち長田 ${ }^{4}$ は, 畄炎感染マウス肝の核酸及 び橉偊白分劃に於ける $\mathrm{P}^{32}$ 活性度を Schneider 法年飞より求め, 所謂内淢期飞一致して增大 することを認めて, 肝組織内の核酸に関連し た物質に激しい変動の抽こることを推察して いる.

更に教室内田 ${ }^{2)}$ す同様の研究法により肺， 脾，堅飞於て子脳炎の内臓期飞一致して，ウ イルスにより宿主細胞の核酸を中心とせる物 質に変動の扮こるととを観察している.

Tuttle ${ }^{29)}$ 等によれば，成熟動物の朋臓の様 な增殖休止埛器では，外来の放射性燐は既存 の核酸分子中の標識されていない燐の一部と 交替するに止り，この場合核酸矛子中の放射 橉の増加はそれk相当量の非放射性燐 ( $\mathrm{P}^{31}$ ) の堅失を意味するが，これに反し增殖力の旺 盛な幼若動物の䑏器, 腫㾤細胞, 或は白血病 のリンパ組織等，又成熟動物でも核酸成分飞 富を生産物をつくる臟器，例えばリンパ球を 造成する類りンパ組織等では，与えられた放 射性橉は核酸磷の新生飞多く使用され従つて これらの㖑器の核酸橉の比放射能は, 他の䑏 器のそれに比べ大きくなる訳で, 核酸橉の比 放射能から核酸代謝の動的な面を観繁するこ とが出来ると云つている。

体内に投与された $\mathrm{P}^{32}$ は，脳て於ては䒠験 期間を通じ潮次增加115) するといわれ，他の 組織飞於ては 10 時間前後飞最大に達し，後 減少するととが報ぜられているが(5)，腹腔内 K $\mathrm{P}^{32}$ を投与する場合には朋飞蓄皘する速度 が極めて速い(5)といわれている。

動つて私の上記実験成績を検討してみるに， 潜伏期初期即ち所葫内㖪期初期飞一致して,
肝飞於ける核酸燐比放射能は顕著なる増大を 認め，とれは脳内接種法と異り高濃度のウ1 Nスが腹腔内に接種せられたが為に，肝組織 に於ける核酸代謝が非常飞元進しているすの 々推察される。

又脳に於ては，その核酸燐比放射能は潜伏 期初期より漸次增大し，発症期に入つて急飞 增大の傾向を示すが，これは脳资の脳盗葡期 に一致して脳に於ける核酸代謝に著しい変動 が莣起せるためと思われる。

然し以上の成績を吟味するに当つては， $\mathrm{P}^{32}$ 自身が放射する $\beta$ 線の核酸代謝に及ぼす影響 を考虑せ朴ならない。

この問題に関しては既に私"1)は脳炎罹患、 ウス歲器の核酸量の変動の面から研究し, $\mathrm{P}^{32}$ $の \beta$ 線が脳炎ウイルスの堌殖を或る程度抑制 乙，発症並に死亡日数を延長せしぬることを 認めたが，教室方円9) も正常マウスに $\mathrm{P}^{32}$ を $10 \mu \mathrm{c}$ 投与し，脳，肝，肺，腎飞於ける核酸 の消長を追求し，RNA-Pは著変なくDNA-P は肝に於てのみ投与 6 時間後に減少の傾向を 認めている.

Jones ${ }^{21)}$ は肝に於ける $\beta$ 線放射の強さに 一致して乳灙の DNA 形成の低下を認め, Hevesy ${ }^{20)}$ によればレ線は DNA の枟換率を 低下せしめるといつている。

かくの如く私の実験炕於てす $\mathrm{P}^{32}$ Kよる $\beta$ 線の核酸代謝への抑制を，勿論考虑せねばな らないが刘照群に比し著しい核酸燐比放射能 を示したことは，高濃度のウイルス接㮔によ り生ずる $\beta$ 線の影響に5ち勝つてウイルスが 殴盛な增殖を示し，すつて核酸代謝の元進を みるすのと推察される。

次に日本畄炎感染マウス缄器の核酸量飞関 しては，潜伏期に於ては脸及び肝の DNA-P， RNA-P は共に対照群に比し著変をみず，発 症期に於て脳，肝共飞 DNA-P の 增量する ことが認められているが12)，私の上記帮験に 於ても脳飞於ては発症期初期上り增量し, 肝 飞於ては発症期後期に於て增大が観察され た.

然かし脳に於ては核酸量の增量と比放射能 
の増大とは平行するる，肝飞於ては逆汇減少 をみ，核酸量の增減と比放射能とは必ずしる 相伴わないと推察される。

これと関しては難波8) 生理的又は病理的 機能と核酸代謝とを結びつける場合, 量的推 移と比放射能の推移とを明瞭に区別する必要 があると云つている。

以上私は今回の実験仿於てウイルス腹㓐内 接種マウス脳及び肝に於ける核酸代謝を，動 的把握の目的上り喏器核酸橉比放射能を求め て追求し, 肝では潜伏期初期化脳では発症期 後期飞頙著なる比放射能の增大を認め，肝飞

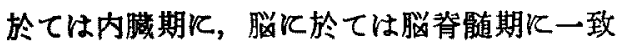
して，ウイルス感染飞ょり核酸代謝の充進せ ることが推察せられ，これは既に教室長田》 飞より施行せられし脳内接璉法の実験結果と 同一の傾向を示し，もつてウイルス接軽法の 如何て拘わらず，脳炎の全身感染症としての 特性を明か飞し得て, 誠に興味深く感ぜられ る.

\section{第五章 結 論}

私以腹腔内日本脳炎病毒接㮔マウス脳及び 肝の核酸代謝を $\mathrm{P}^{32}$ を态用してその動的变化 を追求せんとし, Schneider 法 ${ }^{26)}$ 及び Fiske-

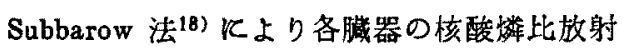
能を求めて研究し, 次の如き結果を得た。

文

1)稲永他 1 名 : 脳と神経, 5巻, 164頁, 昭和28年.

2) 内田：岡山医学会雑誌，68巻，5号，昭和31年。

3）錯方，高木：日本医学及び䗦康保陨，3269号， 271 頁, 昭和17年.

4）辰田：日本内科学会䧴誌，44巻，93頁，炤和30 年.

5）㦷訪：日本脑炎，1948 1949，日脳調研協，25 頁，昭和25年。

6) 中：生体の科学，4，106 112, 昭和27年.

7) 中沢：ラチオアイントーブ，3巻，2号，12月 号, 昭和29年.

8）難波：岡山医学会雜誌，67巻，1号，昭和31年.

9) 方円：即刷中.

10）堀田他 2 名：Virus，2卷，26頁，临和27年.
1. 脳に於てはウイルス接種群の核酸燐比 放射能は，潜伏期ではその対照群に比し著変 は認められないが，発症期に入ると益々対照 群飞此し有意の差を認め, 発症期後期 ( $\mathrm{P}^{32}$ 注 射後24時間）飞於て最大に達する。

旰に於てはウイルス接種群の核酸橉比放射 能は, 潜伏期初期 ( $\mathrm{P}^{32}$ 注射後 6 時間) 飞, その対照群に此し非常飞顕著なる増大を示し たが，発症期炕入ると急激なる減少の傾向を 示した.

これは潜伏期即ち日本脳炎の内䁍期に一致 して肝に，その脳脊䯣期に一致して脳に，核 酸代謝に激しい変動の挌とりしてとを暗示し ている.

2. 以上の実験結果は，既《長田4)，方円99， 内田 ${ }^{2)}$ Kよつて施行せられし脳内接種法によ る実験結果と同一傾向にあることを確認し た.

3. 核酸量の増減と此放射能とは必らずし す相伴わない，故化生理的又は病理的機能と 核酸代謝とを結びつける場合，今後は量的推 移と比放射能の推移とを明瞭に区別する必要 があると云う難波早)の研究結論を，上記実験 成績により確認した。

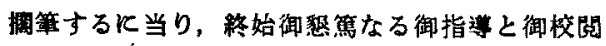
を賜わつた恩㸝平木敉授に深甚の㴬意を表する。

献

11）松久：岡山医学会雜誌，68卷，11号，別卷，69 頁，昭和31年。

12）松久 ·同上, 59頁.

13) Chaikoff, I. L. : Physiol. Review, 22, 291 317, 1942.

14) Cohen, S. S.: J. Biol. Chem.. 174, 295, 1948.

15) Cohn, W. E., Greenberg, D. M. : J. Biol. Chem.,

16) Dawson, R.M.C.: Biochem. J., 55, 507 517, 1953.

17) Dawşon, R.M. C. and Richter, D.. Proc. Roy. Soc. B. 137, 252 267, 1950.

18) Fiske-Subbarow: J. Biol. Chem., 66, 375, 
1952.

19) Graham, A.F., Mc Clelland, L. : Nature, 163, 949, 1949.

20) Hevesy: Biochem. J., 17, 439, 1923.

21) Jones, B., Cited in Hevesy. G.: Advances in Biol. Med. Phys. 1, 409, 1948.

22) Lindberg, O. and Ernster, L.: Biochem. J., 46, 43 47, 1950.

23) Putman, F. W. : Kozloff. L. M. Science. 108, 386, 1948.

24) Sacks, J. and Gulbreth, G. G. . Am. J. Phy- siol., 165, 251 256, 1951.

25) Schmidt e. Thannhauser : J. Biol. Chem. Vol. 161, P. 83, 1945.

26) Schneider: J. Biol. Chem., 161, 293, 1945.

27) Stanley, W. M. : J. Gen. Physiol. 25, 881, 1942.

28) Tuttle et al. = J. Clin. Invest., 20, 57, 1941.

29) Tuttle, 1. W., Erf, L. A. and Laurence, J. H. : J. Clin. Invest. 20, 57, 1947.

\section{Experimental Studies on Japanese B Encephalitis with} the Radioactive $\mathrm{P}^{32}$

\section{Part 3}

\section{Investigation Of Nucleic Acid Metabolism in the Organs, especially in Brain And Liver, of Mice Inoculated Intraperitoneally with Japanese B Encephalitis Virus from the View. point of the Specific Activity of P32.}

By

\section{Mitsuo Matsuhisa}

Dept. of Internal Medicine, Okayama University, Medical School.

(Director : Prof. K. Hiraki)

Nucleic acid metabolism in brain and liver, which had been formerly investigated by the measurement of $\mathbf{P}^{32}$ activity, was examined from the viewpoint of the specific activity of $\mathrm{P}^{32}$ in order to make clear the nucleic acid metabolism in its progressive form.

As in my last experiment, Japanese B Encephalitis Virus was intraperitoneally inoculated.

$P^{32}$ was intraperitoneally injected into the mice respectively 48 and 120 hours after they were inoculated with the virus, and after 6 and 24 hours, the nucleic acid metabolism in brain and liver was observed from the point of view of the $\mathrm{P}^{32}$ specific activity.

As the control objects, the healthy mice injected intraperitoneally with $\mathrm{P}^{32}$ were used.

An increase of the $P^{32}$ specific activity in liver was recognized during the incubation period, especially in its earlier stage.

This fact, as Osada once reported, seems to imply that rapid netabolic changes of the nucleic acid in liver take place during the incubation period or the so-called visceral phase of Japanese B Encephalitis.

The $\mathrm{P}^{32}$ specific activity in liver at the later stage of infection decreases in spite of the increase of nucleic acid amount; and the ups and downs in nucleic acid amount does not always go parallel with the $\mathrm{P}^{32}$ specific activity. 